\title{
Kinetics of methane and carbon dioxide sorption and sorption-induced expansion of coal - kinetic equations assessment
}

\author{
Katarzyna Czerw' ${ }^{1, a}$, Agnieszka Ćwik ${ }^{1}$, Paweł Baran ${ }^{1}$ and Katarzyna Zarębska ${ }^{1}$ \\ ${ }^{1}$ AGH University of Science and Technology, Faculty of Energy and Fuels, Aleja Mickiewicza 30, 30-059 Cracow, Poland
}

\begin{abstract}
The aim of this study was to investigate the ability of kinetic equations to describe the sorption kinetics and expansion rate of solid coal samples. In order to address his issue the sorption kinetics of methane and carbon dioxide on bituminous coals were studied. At the same time, the changes occurring in the sample's overall dimensions, which accompanied sorption processes, were monitored. Experiments were carried out at high pressure by means of the volumetric method on a cubicoid solid samples. Several literature-based modeling approaches and equations are proposed to fit the kinetic curves of gas deposition, as well as the adequate kinetics of coal swelling. First equation represents the traditional approach to interpret experimental data in terms of fast and slow sorption process and consider the combination of two first-order rate functions. The other empirical kinetic equations are: the pseudo-second-order kinetic equation (PSOE), Elovich equation and the stretched exponential equation (SE). Two of the four equations are suitable to describe the kinetics of methane and carbon dioxide sorption and have been successfully used to quantify the observed dilatometric phenomena rates. The stretched exponential equation gave the best fit to the experimental data.
\end{abstract}

\section{Introduction}

Interest in sequestration of carbon dioxide and the enhanced coal bed methane recovery (ECBM) process, that is, recovery of methane from carboniferous deposits with simultaneous $\mathrm{CO}_{2}$ sequestration results primarily from ecological issues, for example to lower the emission of carbon dioxide, but also has prospective economic aspects [1-5]. Investigation and understanding of the relations between the expansion/contraction of hard coal and the amount of gas sorbed in its porous structure in coal-mine gas (mainly $\mathrm{CH}_{4}$ and $\mathrm{CO}_{2}$ ) systems are fundamental issues in carbon dioxide sequestration and recovery of methane from carboniferous formations. Important issues that need to be focused on are coal-gas $\left(\mathrm{CH}_{4}, \mathrm{CO}_{2}\right)$ interactions within a coal bed, their analytical and numerical description and the underlying mechanisms [6].

Mine gases are deposited in coal beds in different forms: (1) adsorbed in micropores and on the surface of larger pores; (2) absorbed in the coal molecular structure; (3) as free gas in fissures and larger pores, which becomes significant at higher sorbate pressures; and (4) dissolved in deposit waters [7-8]. Investigation of vapors and gases sorption process on solid hard coal samples has shown the occurrence of sorption-induced swelling of the sorbent. Further research into this phenomenon has led to the conclusion that coal is a biporous, involving transport and sorption process. It is a system in which eleveted pressure of gases causes compression of microporous regions and expansion of macropores. Gas sorption gives an opposite effect of induced expansion of microporous regions and narrowing of transport pores and the in situ a decrease of system permeability [9-10]. The majority of research in the field shows that the swelling of coal is approximately proportional to the amount of sorbed gas implicating a linear relation between sorption and expansion [6, 11-16]. Studies that suggest non linear dependence are a minority $[9,17]$.

Sorption kinetics concerns the time dependence or rate of reactions, usually described in terms of a mathematical relationship between the amount of sorbed substance, equivalent to weight gain or volume of accumulated agent, and time. To interpret and quantify the observed gas uptake rates in coal two models have been used: unipore model, based on the solution to Fick's second law for spherical symmetric flow [1822] and bidisperse sorption/diffusion gas transport model for coals characterized by two distinct pore systems [18, $20,23-28]$. It is generally confirmed that the amount micropores increase and mesopores decrease with coal rank. As a result, although not generally confirmed, unipore models seem to better represent the sorption kinetics of high rank coals (medium-volatile bituminous coal to anthracite) while bidisperse models better represent low rank coals [23].

In the light of this consideration, in our previous investigation we assumed that it might be possible to use the same approach to determine equations that provide

\footnotetext{
a Corresponding author: kczerw@agh.edu.pl
} 
a mathematical description of the kinetic curves for both sorption and swelling of coal [29]. To obtain the experimental results for further mathematical evaluation, sorption of methane and carbon dioxide on cuboidal hard coal samples was investigated at high pressure. The pressure value of gas in the sample cell at the beginning of experiments was about $4 \mathrm{MPa}$. At the same time as the sorption kinetics were monitored, changes of the sample's overall dimensions accompanying the sorption processes were measured. Coal samples (high-volatile bituminous C) were obtained from the Brzeszcze-Silesia mine [29]. Experiments were performed using the apparatus and test procedures described by Majewska et al. [17]. Our findings translate into general conclusions:

- for two equations based on the bidisperse gas transport model, the equation proposed by Busch et al. [18] gives better fit than the equation proposed by Siemons et al. [26],

- the pseudo-second-order equation (PSOE) of Marecka and Mianowski [30] was unsuitable for the data

- the Elovich equation fits the results well, because the sorption and sorption-induced expansion were far from equilibrium, however, because the function goes to infinity it should be avoided

- the stretched exponential equation gives the best fit and is in very good agreement with the experimental results [29].

In this study, we evaluated the ability of four sorption kinetic equations to describe sorption kinetics and the rate of expansion/contraction of cuboidal hard coal samples in coal-carbon dioxide and coal-methane systems in evaluated pressure range, as the pressure value of gas in the sample cell at the beginning of experiments was somewhat above $1 \mathrm{MPa}$. First approach proposed by Busch et al. [18] consider the combination of two first-order rate functions and represent the traditional approach to interpret experimental data in terms of fast and slow sorption process. The other empirical kinetic equations are: the pseudo-second-order kinetic equation (PSOE) proposed by Blanchard et al. [31], in original time-integrated form [32]; Elovich equation developed to describe kinetics of chemisorption [33-34] and stretched exponential equation (SE) also known as the KEKAM equation [35-36].

\section{Experimental methods}

Primary experiments were performed using the apparatus and test procedures described by Baran et al. [11]. The experimental program uses a purpose-built apparatus, enabling the concurrent measurements of sorption and dilatometric parameters of cuboid-shaped coal samples. Measurements of sorption capacity are taken by the manometric method. The device is placed inside a water thermostat, maintaining a constant temperature of $298 \mathrm{~K}$. Gas of known pressure and volume becomes decompressed and moves from the reference cell to the sample cell containing the sorbent. Knowing the dead volume of the apparatus and the volume of the dosing unit, the amounts of absorbed/adsorbed gas can be computed on the basis of gas laws. Coal sample deformations were measured with a strain gauge engineered at the Strata Mechanics Research Institute of the Polish Academy of Sciences. Linear strains are measured with an electric resistant wire strain gauge incorporating a resistance (bridge) transducer [11].

Table 1. Specification of coal samples: proximate and ultimate analysis.

\begin{tabular}{|c|c|c|c|c|}
\hline \multicolumn{5}{|c|}{ Proximate analysis } \\
\hline Coal & $\mathrm{W}^{\mathrm{a}}[\%]$ & $\mathrm{A}^{\mathrm{a}}[\%]$ & $\mathrm{V}^{\mathrm{daf}}[\%]$ \\
\hline Pniówek & 0.68 & 3,78 & 25.50 \\
\hline Budryk & 0.70 & 1.80 & 32.60 \\
\hline \multicolumn{5}{|c|}{ Ultimate analysis } \\
\hline Coal & $\mathrm{C}^{\text {daf }}[\%]$ & $\mathrm{H}^{\mathrm{daf}}[\%]$ & $\mathrm{N}^{\text {daf }}[\%]$ & $\mathrm{S}^{\text {daf }}[\%]$ \\
\hline Pniówek & 84.96 & 4.60 & 1.70 & 0.58 \\
\hline Budryk & 90.84 & 5.81 & 1.45 & 0.65 \\
\hline
\end{tabular}

$W^{\text {a }}$ : moisture content, air-dried basis, $A^{\text {a }}$ : ash content, air-dried basis, $\mathrm{V}^{\text {daf: }}$ volatile matter content, air-dried basis, $C^{\text {daf: }}$ content of element $\mathrm{C}$, dry-ash-free basis, $H^{\text {daf }}$ : content of element $\mathrm{H}$, dry-ash-free basis, $N^{\text {daff: }}$ content of element $\mathrm{N}$, dry-ash-free basis, $S^{\text {daf. }}$ content of element $\mathrm{S}$, dry-ash-free basis

Table 2. Specification of coal samples: maceral composition.

\begin{tabular}{|l|c|c|}
\hline \multicolumn{1}{|c|}{ Coal } & Pniówek & Budryk \\
\hline Telinite [\%] & 0.6 & 0.2 \\
\hline Collotelinite [\%] & 26.0 & 15.2 \\
\hline Vitrodetrinite [\%] & 1.0 & 0 \\
\hline Collodetrinite [\%] & 23.0 & 48.3 \\
\hline Corpogelinite [\%] & 1.0 & 0 \\
\hline Gelinite [\%] & 1.0 & 0.6 \\
\hline Total vitrinite [\%] & $\mathbf{5 2 . 6}$ & $\mathbf{6 4 . 3}$ \\
\hline Sporinite [\%] & 5.3 & 3.8 \\
\hline Resinite [\%] & 0 & 0.4 \\
\hline Liptodetrinite [\%] & 3.0 & 0 \\
\hline Cutinite [\%] & 0 & 1.0 \\
\hline Total liptinite [\%] & $\mathbf{8 . 3}$ & $\mathbf{5 . 2}$ \\
\hline Fusinite [\%] & 20.8 & 10.7 \\
\hline Semifusinite [\%] & 8.0 & 5.2 \\
\hline Macrinite [\%] & 1.9 & 2.0 \\
\hline Micrinite [\%] & 0 & 0.2 \\
\hline Funginite [\%] & 1.6 & 5.3 \\
\hline Inertodetrinite [\%] & 6.8 & 7.1 \\
\hline Total inertinite [\%] & $\mathbf{3 9 . 1}$ & $\mathbf{3 0 . 5}$ \\
\hline Mineral matter [\%] & $\mathbf{0}$ & $\mathbf{0}$ \\
\hline
\end{tabular}

For the purpose of measurements, a cuboid samples $(18 \times 18 \times 40 \mathrm{~mm})$ were cut from the basic coal fragments, obtained from the Pniówek mine and Budryk mine. ). The results of analysis performed on the basic coal samples are shown in Table 1 and Table 2. Experiments on coal Pniówek followed test procedures described by Baran et al. [11]. Experiment on coal 
Budryk were performed using the apparatus and test procedures described by Majewska et al. [17].
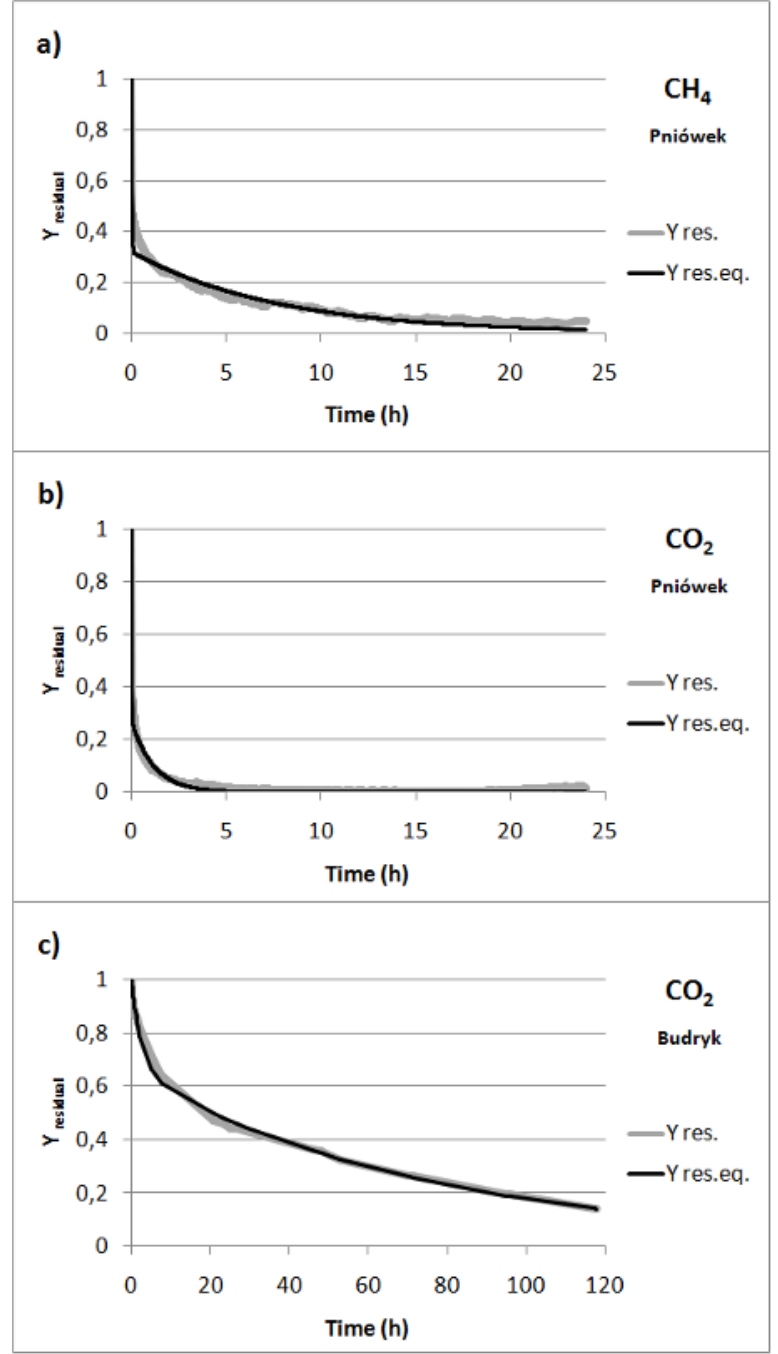

Figure 1. Application of the Busch equation (Eq. (1)) to the kinetics for (a) $\mathrm{CH}_{4}$ and (b) $\mathrm{CO}_{2}$ sorption on coal Pniówek and (c) $\mathrm{CO}_{2}$ sorption on coal Budryk.

On the opposite walls of coal samples, resistance strain gauges were attached, arranged alongside and transverse to the bedding plane. The sample was connected to the strain gauge and placed inside a test ampule. Prior to the main experiment, the sample was degassed, the dead volume of the sample cell was determined using helium, and the system was degassed again to achieve the static vacuum of the order of $10^{-2} \mathrm{~Pa}$. Carbon dioxide or methane was then admitted to the reference cell, and when the constant pressure value was established, the gas was admitted to sample cell. The moment that gas was introduced, the recording of the kinetics of the pressure drop in the measurement system began. The values of the sorption progress $\left(\mathrm{V}\left[\mathrm{NTPcm}^{3} / \mathrm{g}\right]\right)$ were then calculated. The data on kinetics of linear strains of the coal sample were stored simultaneously in the internal memory of the strain meter [11]. On the basis of the obtained kinetics of coalinduced linear strains in the perpendicular $\left(E_{\perp}[\%]\right)$ and parallel $\left(\mathrm{E}_{/ /}[\% \mathrm{o}]\right)$ to the bedding plane, the kinetics of volumetric strains (E [\%o]) were calculated in accordance with the relation: $\mathrm{E}=\mathrm{E}_{\perp}+2 \mathrm{E} / /$.

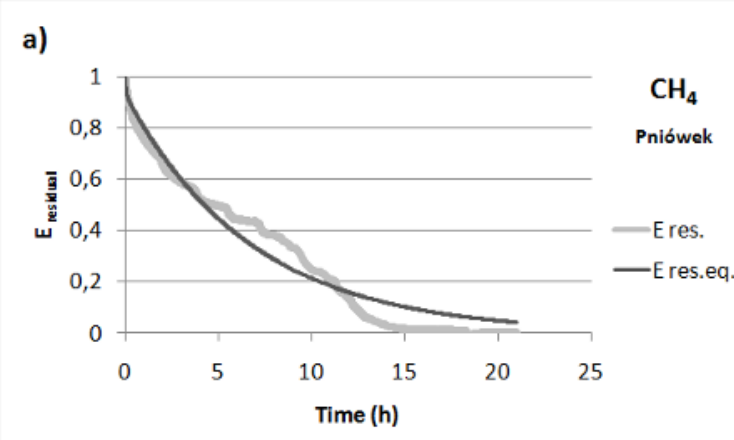

b)

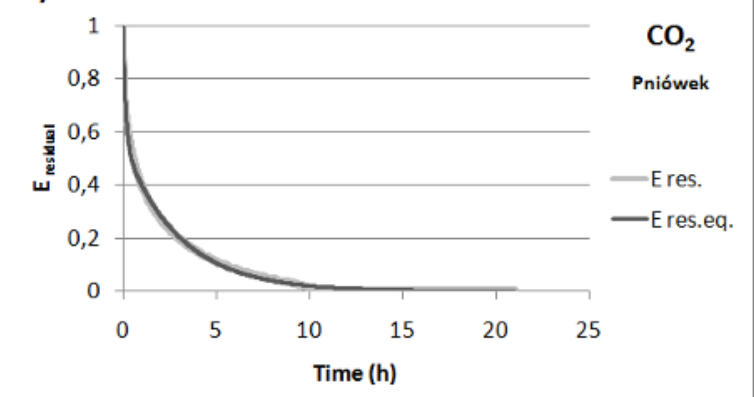

c)

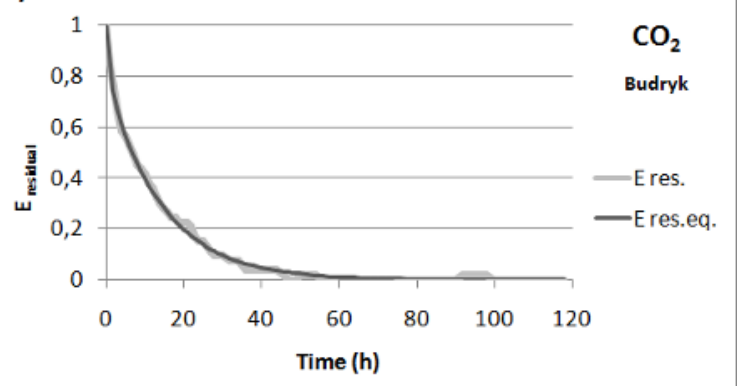

Figure 2. Application of the Busch equation (Eq. (2)) to the kinetics for (a) $\mathrm{CH}_{4}$ and (b) $\mathrm{CO}_{2}$ sorption-induced swelling of coal Pniówek and (c) $\mathrm{CO}_{2}$ sorption-induced swelling of coal Budryk.

\section{Results and discussion}

\subsection{Kinetic equations}

The approach of Busch et al. [18] is based on the bidisperse sorption/diffusion model and describes the gas sorption kinetics as a linear combination of two first-order rate functions because the transport is being split to fast and slow process:

$$
Y_{\text {residual }}(t)=Y^{\prime} \exp \left(-k^{\prime} t\right)+Y^{\prime \prime} \exp \left(-k^{\prime \prime} t\right)
$$

$Y_{\text {residual }}\left(Y_{\text {res }}\right)$ stands for the relative residual (unoccupied) sorption amount, $k^{\prime}$ and $k^{\prime \prime}$ are different rate constants, $Y^{\prime}$ and $Y^{\prime \prime}$ (with $Y^{\prime \prime}=1-Y^{\prime}$ ) are normalized sorption at equilibrium [18].The expansion kinetics can be described by the equation: 


$$
E_{\text {residual }}(t)=E^{\prime} \exp \left(-k^{\prime} t\right)+E^{\prime \prime} \exp \left(-k^{\prime \prime} t\right)
$$

where $E_{\text {residual }}\left(E_{\text {res }}\right)$ is the relative residual expansion, which is the potential relative swelling, $k^{\prime}$ and $k^{\prime \prime}$ are different rate constants, and the parameters $E^{\prime}$ and $E^{\prime \prime}$ represent expansion at equilibrium (with $E^{\prime \prime}=1-E^{\prime}$ ).

The mathematical form of the PSOE was first proposed by Blanchard et al. [31] to describe the kinetics of heavy metal removal by natural zeolites. It is the most commonly used equation to describe sorption kinetic data [32]. The general time-integrated form of the equation is:

$$
V(t)=V_{e q} \frac{k V_{e q} t}{1+k V_{e q} t}
$$

where $V_{e q}$ is the equilibrium sorption amount and $k$ is the rate constants. For the purpose of this analysis, Eq.(3) was transformed to Eq. (4) for the swelling progress:

$$
E(t)=E_{e q} \frac{k V_{e q} t}{1+k V_{e q} t}
$$

where $E_{e q}$ is the equilibrium sorption amount and $k$ is the rate constants.
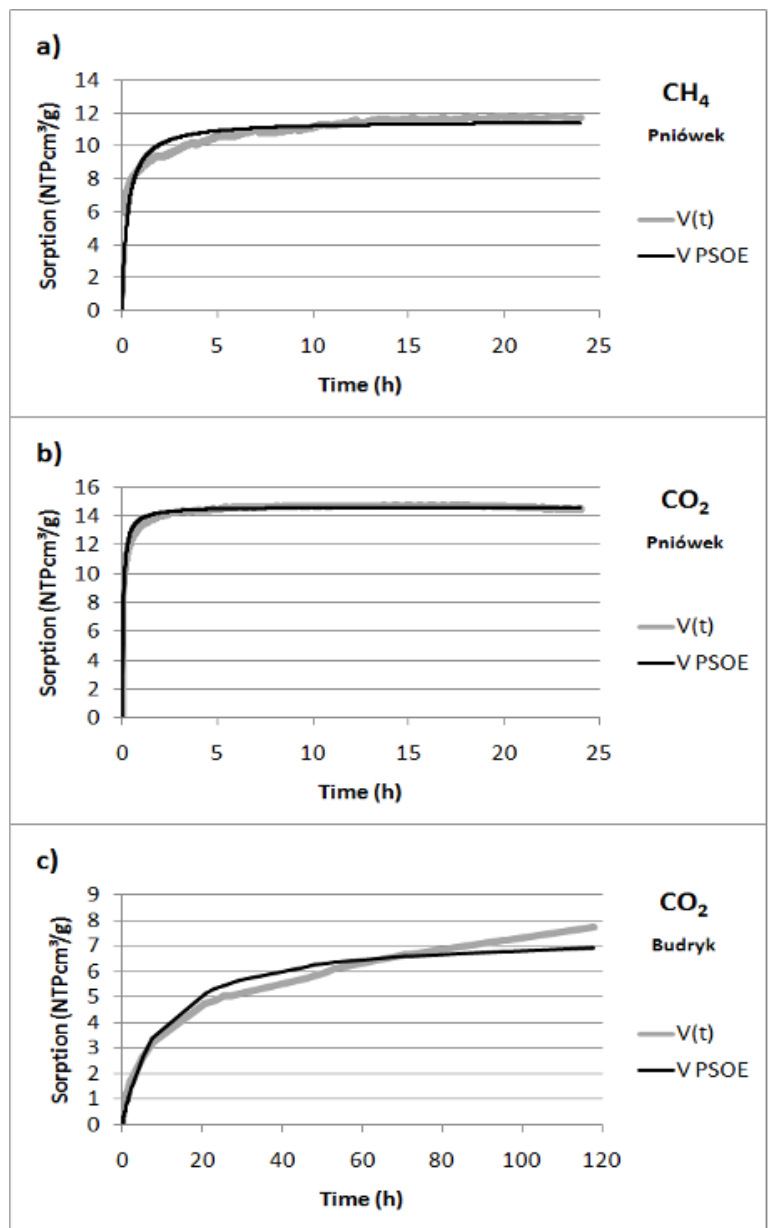

Figure 3. Application of the PSOE (Eq. (3)) to the kinetics for (a) $\mathrm{CH}_{4}$ and (b) $\mathrm{CO}_{2}$ sorption on coal Pniówek and (c) $\mathrm{CO}_{2}$ sorption on coal Budryk.
The Elovich equation [33-34] corresponds to chemisorptions. It is characterized by the two parameters $A$ and $B$.The sorbed amount has no maximum value it goes to infinity and should be avoided. However, it was used in this analysis in its integrated forms:

$$
\begin{aligned}
& V(t)=\frac{1}{B} \ln (A B t+1) \\
& E(t)=\frac{1}{B} \ln (A B t+1)
\end{aligned}
$$

The stretched exponential (SE) equation was developed as a global kinetic equation by Kolmogorov, Erofeev, Kozeeva, Avrami, and Mampel, and it is called the KEKAM equation [35-36]. It is characterized by parameter $A$ and rate coefficient $k$. For the purpose of this analysis, the following forms of the equation were used:

$$
\begin{aligned}
& V(t)=V_{e q}\left\{1-\exp \left[-(k t)^{A}\right]\right\} \\
& E(t)=E_{e q}\left\{1-\exp \left[-(k t)^{A}\right]\right\}
\end{aligned}
$$

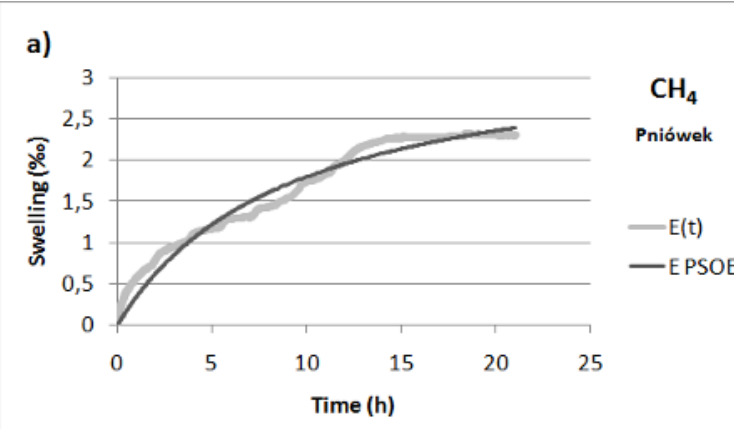

b)

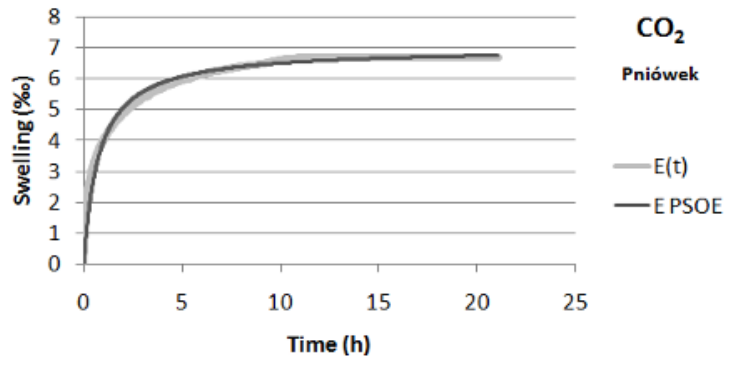

c)

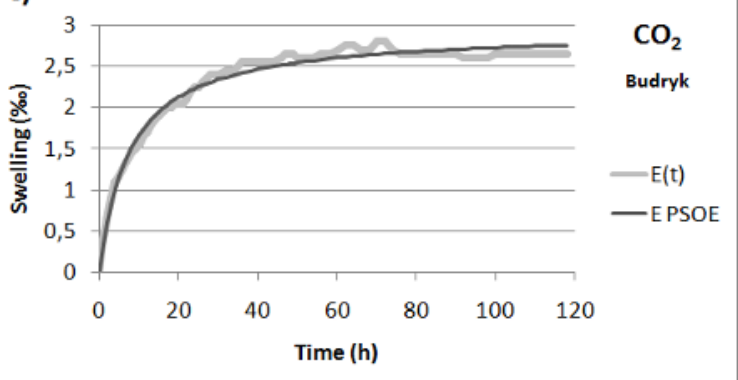

Figure 4. Application of the PSOE (Eq. (4)) to the kinetics for (a) $\mathrm{CH}_{4}$ and (b) $\mathrm{CO}_{2}$ sorption-induced swelling of coal Pniówek and (c) $\mathrm{CO}_{2}$ sorption-induced swelling of coal Budryk. 


\subsection{Analysis}

Figs. 1-7 show experimental kinetic curves of the accumulation of $\mathrm{CH}_{4}$ and $\mathrm{CO}_{2}$ in the porous structure of coal and the kinetic curves of coal expansion that accompany the sorption processes as well as plots resulted from the application of the kinetic equations.

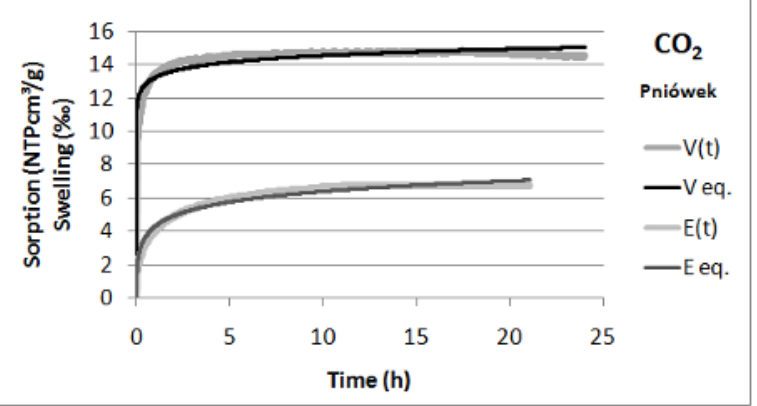

Figure 5. Application of the Elovitch equations to the kinetics for $\mathrm{CO}_{2}$ sorption (Eq. (5)) and the sorption-induced coal swelling (Eq. (6)) of coal Pniówek.

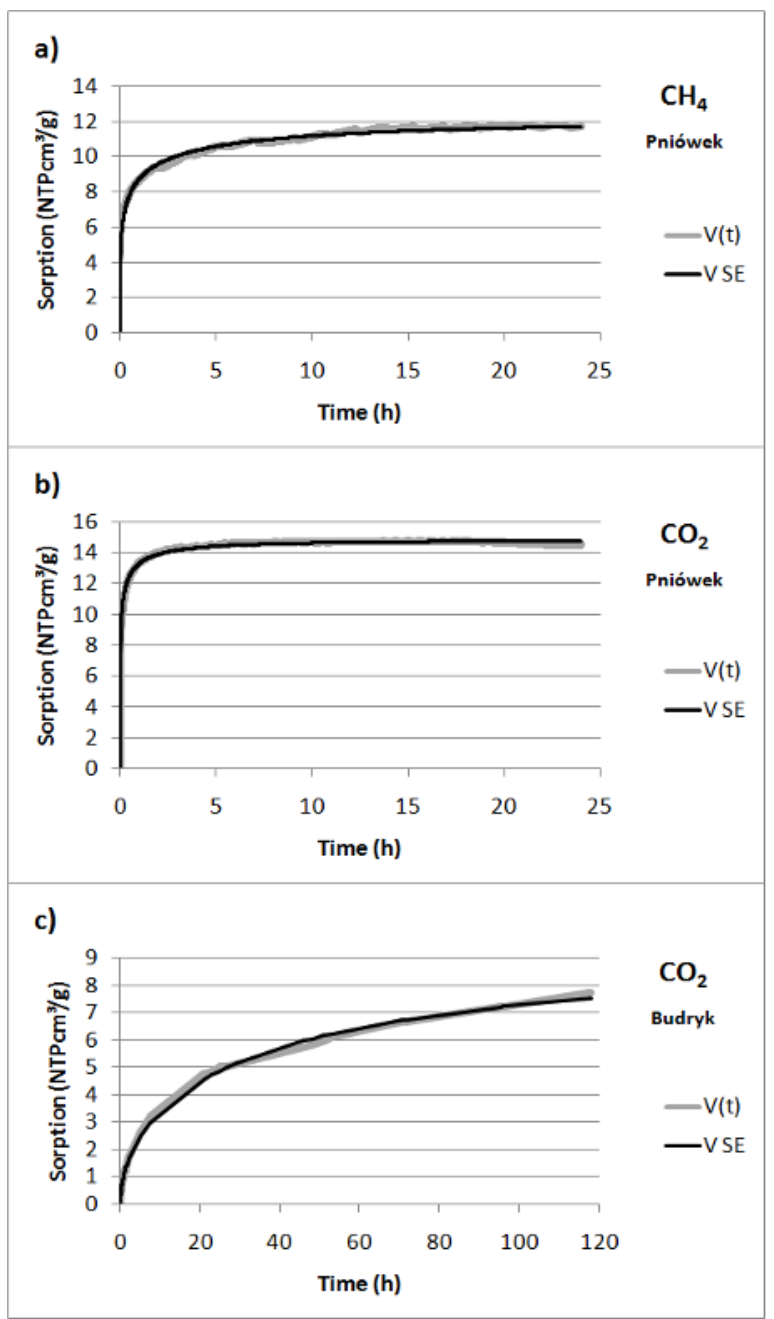

Figure 6. Application of the SE equation (Eq. (7))

to the kinetics for (a) $\mathrm{CH}_{4}$ and (b) $\mathrm{CO}_{2}$ sorption on coal

Pniówek and (c) $\mathrm{CO}_{2}$ sorption on coal Budryk.
The fitting results of Busch et al. [18] equation are shown in Figs. 1-2. The residual (unoccupied) relative sorption amount ( $Y_{\text {residual }}$ ) (Fig. 1) or the amount of residual expansion $\left(E_{\text {residual }}\right)$ (Fig. 2) is shown on the $y$ axis and the $x$ axis is time [h]. The fitting results of the PSOE, Elovitch equation, and SE are shown in Figs. 3-7, respectively. In these figures, the $y$ axis is the amount of sorbed gas (Sorption $\left[\mathrm{NTPcm}^{3} / \mathrm{g}\right]$ ) and/or the volumetric swelling of coal (Swelling [\%o]) for parts $\mathrm{c}$ and $\mathrm{d}$. The $x$ axis is time [h].

The first approach using the equation of Busch et al. based on two combined first-order rate functions gives a reasonable fit to the experimental data for $\mathrm{CO}_{2}$ sorption and swelling for both coals, but for $\mathrm{CH}_{4}$ the approximation seems to be second best in the case of the sorption and expansion data (Figs. 1-2).

The PSOE shows good agreement with the experimental data obtained for $\mathrm{CO}_{2}$ sorption and swelling for coal Pniówek (Figs.3b and 4b). Application of the equation to the experimental data of sorption $\mathrm{CH}_{4}$ on coal Pniówek and $\mathrm{CO}_{2}$ on coal Budryk is unsuitable (Fig. 3).

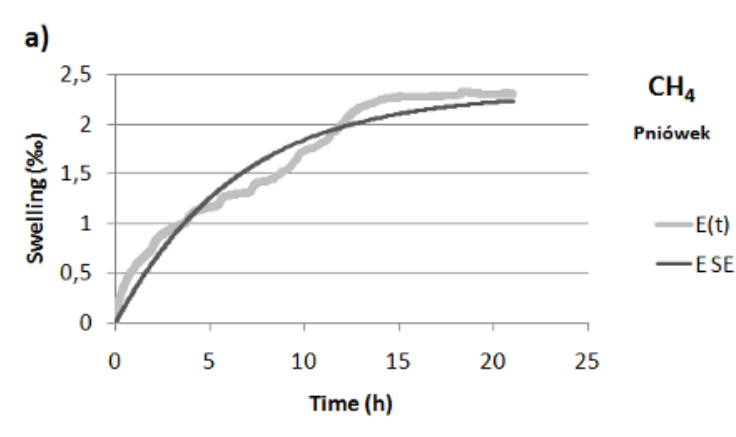

b)

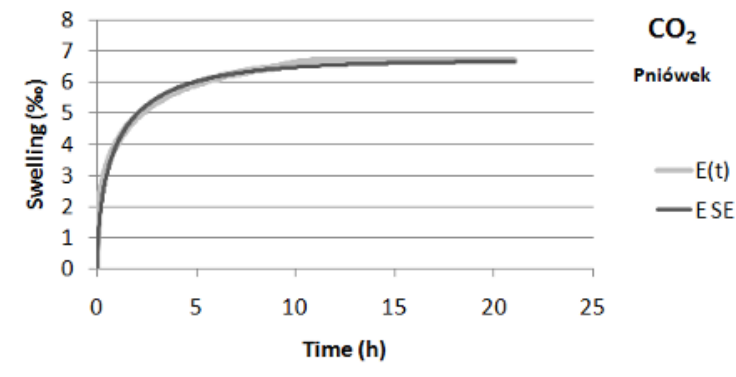

c)

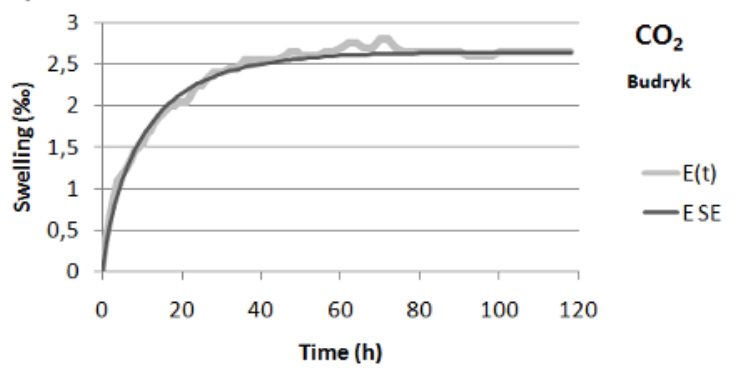

Figure 7. Application of the SE equation (Eq. (8))

to the kinetics for (a) $\mathrm{CH}_{4}$, (b) $\mathrm{CO}_{2}$ sorption-induced swelling of coal Pniówek, (c) $\mathrm{CO}_{2}$ sorption-induced swelling of coal Budryk. 
However, it seems to be quite suitable for the corresponding swelling kinetics (Fig. 4). The PSOE underestimates the equilibrium values for lower rate sorption (Fig. 3a,c). For the two main components of mine gas, methane has lower diffusivity, which is why its sorption rate is lower than that of carbon dioxide $[18,20,24]$. The conclusion is that the PSOE might be unsuitable for experiments with solid samples, in contrast to traditional research of sorption on powders and grain fractions, that take longer time to reach equilibrium state.

From Fig. 5, it is clear that the Elovitch equation is unable to accurately describe the sorption kinetic of $\mathrm{CO}_{2}$ as well as the $\mathrm{CO}_{2}$-induced swelling behavior of coal Pniówek. The same fitting results were obtained for $\mathrm{CH}_{4}$ sorption kinetic on coal Pniówek and $\mathrm{CH}_{4}$-induced swelling behavior for both coals and for that reason they are not included herein. As mentioned, because of the form of the equation the calculated sorbed goes to infinity and definitely should be avoided in cases like these.

Figs. 6-7 shows the results of applying the SE kinetic equation. The fitted results are in excellent agreement with the test results for both sorbats and both coals. This equation is the most promising approach to fit the experimental results of both the sorption processes and expansion phenomena of solid coal samples despite the rate of the process and time required to reach equilibrium state.

\section{Conclusions}

Four approaches were used to fit experimental sorption and dilatometric data of methane and carbon dioxide sorption to two coals. Equation based on the bidisperse gas transport model, proposed by Busch et al. [18] is very good to interpret and quantify observed gas uptake and expansion rates in coal. The PSOE is suitable for he obtained data, except the sorption kinetics with a lower rate than that obtained for $\mathrm{CO}_{2}$ sorption on coal Pniówek. The Elovich equation does not fit the results obtained in this study, because the sorption and sorption-induced expansion processes reached close to equilibrium state and the problem of a lack of a maximum sorbed amount value in the equation did occur. Therefore the function should be avoided. The SE equation gives the best fit and is in very good agreement with all experimental results.

\section{Acknowledgments}

Financial support for this study was provided by the AGH University of Science and Technology (framework no. 11.11.210.244).

\section{References}

1. B. Dutka, M. Kudasik, Z. Pokryszka, N. Skoczylas, J. Topolnicki, M. Wierzbicki, Fuel Processing Technology 106, 95-101 (2013)
2. G.S. Jodłowski, P. Baran, M. Wójcik, A. Nodzeński, St. Porada, J. Milewska-Duda, Applied Surface Science 253, 5732-5735 (2007)

3. J.P. Kaszuba, D.R. Janecky, Carbon Sequestration and its Role in the Global Carbon Cycle, Geophysical Monograph 183 (2013)

4. M. Wdowin, R. Tarkowski, W. Franus, Arab. J. Sci. Eng. 39, 295-309 (2014)

5. M. Wdowin, R. Tarkowski, W. Franus Int. J. Coal Geol. 130, 79-88 (2014)

6. K. Czerw, Int. J. Coal Geol. 85, 72-77 (2011)

7. M. Mastalerz, H. Gluskoter, J. Rupp, Int. J. Coal Geol. 60, 43-55 (2004)

8. K. Zarębska, G. Ceglarska-Stefańska, Int. J. Coal Geol. 74, 167-174 (2008)

9. Z. Pan, L.D. Connell, Int. J. Coal Geol. 69, 243-252 (2007)

10. H. Seewald, J. Klein, Glückauf - Forschungshefte 47, 149-156 (1986)

11. P. Baran, K. Zarębska, M. Bukowska, Energy \& Fuels 29, 1899-1904 (2015)

12. R.M. Bustin, X. Cui, L. Chikatamarla, AAPG Bulletin 92, 15-29 (2008)

13. X. Cui, M.R. Bustin, L. Chikatamarla, J. Geophys. Res. 112, B10202 (2007)

14. S. Harpalani, G. Chen, Fuel 74, 1491-1498 (1995)

15. S. Ottinger, R. Pini, G. Storti, M. Mazzotti, Adsorption 14, 539-556 (2008)

16. J.D. St. George, M.A. Barakat, Int. J. Coal Geol. 69, $83-115$ (2001)

17. Z. Majewska, G. Ceglarska-Stefańska, S. Majewski, J. Ziętek, Int. J. Coal Geol. 77, 90 $102(2009)$

18. A. Busch, Y. Gensterblum, B.M. Krooss, R. Littke, Int. J. Coal Geol. 60, 151-168 (2004)

19. D. Charrière, Z. Pokryszka, P. Behra, Int. J. Coal Geol. 81, 373-380 (2010)

20. C.R. Clarkson, R.M. Bustin, Fuel 78, 1345-1362 (1999)

21. Z. Pan, L.D. Connell, M. Camilleri, L. Connelly, Fuel 89, 3207-3217 (2010)

22. J.D.N. Pone, P.M. Halleck, J.P. Mathews, Energy \& Fuels 23, 4688-4695 (2009)

23. Busch, A., Gensterblum, Y., Int. J. Coal Geol. 87, 49-71 (2011)

24. X. Cui, M.C. Bustin, G. Dipple, Fuel 83, 293-303 (2004)

25. E, Ruckenstein, S. Vaidyanathan, G.R. Youngquist, Chem. Eng. Science 26, 1305-1318 (1971)

26. N. Siemons, K.-H.A.A. Wolf, J. Bruining, Int. J. Coal Geol. 72, 315-324 (2007)

27. J.Q. Shi, S. Durucan, SPE, paper 84342 (2003)

28. J.Q. Shi, S. Durucan, Fuel 82, 1219-1229 (2003)

29. K. Czerw, K. Zarębska, B. Buczek, P. Baran, Adsorption 22, 791-799 (2016)

30. A. Marecka, K. Mianowski, Fuel 77, 1691-1696 (1993)

31. G. Blanchard, M. Maunaye, G. Martin, Water Res. 18, 1501-1507 (1984)

32. W. Płaziński, J. Dziuba, W. Rudziński, Adsorption 19, 1055-1064 (2013) 
33. C. Aharoni, Y. Suzin, J. Chem. Soc., Faraday Trans. 1. 78, 2321-2327 (1982)

34. C. Aharoni, F.C. Tompkins, Trans. Faraday. Soc. 66, 434-444 (1970)

35. M. Avrami, J. Chem. Phys. 7, 1103-1112 (1939)

36. F. Brouers, O. Sotolongo-Costa, Phys. A 368, 165175 (2006) 